UDC 635.655:631.543

\title{
INFLUENCE OF SOWING TIMES AND SOWING RATES ON BIOMETRIC INDICATORS OF SOYBEAN VARIETIES WITH DIFFERENT VEGETATION PERIOD
}

\section{Moldovan, Zh. Moldovan, S. Sobchuk}

Article info

Received

29.04.2020

Accepted

24.06.2020

Khmelnitsky State Agricultural Experimental Station Institute of Feed Research and Agriculture of Podillya NAAS Samchyky village, Starokostyantyniv district, Khmelnytsky region, 31182, Ukraine

E-mail: moldovan.zh@ ukr.net
Moldovan, V., Moldovan, Zh., Sobchuk, S. (2020). Influence of sowing times and sowing rates on biometric indicators of soybean varieties with different vegetation period. Scientific Horizons, 07 (92), 32-39. doi: 10.33249/2663-21442020-91-6-32-39.

The proposal to agricultural producers of new soybean varieties necessitates their adaptation to certain soil and climatic conditions of cultivation and improvement of certain technological elements (sowing dates, seeding rates, etc.), which will ensure their high productivity and maximum realization of genetic potential.

According to the results of our research, it was found that in all varieties the increase in sowing rate to 900 thousand similar seeds caused an increase in the height of attachment of the lower bean, on average, by 1,0-6,8 cm, while its decrease to 500 thousand similar seeds led to a decrease in this indicator by 0,9-5,7 cm for all sowing dates.

During the whole research period, soybean varieties, depending on sowing dates and sowing rates, formed different numbers of beans: Diadema of Podillya -23-33 un., KiVin-26-44 un., Knyazhna-21-29 un., Khutoryanochka-23-32 un., Triada-2838 un. However, in soybean varieties Diadema Podillya and Khutoryanochka there was no significant difference in the number of beans at different sowing dates, while in varieties KiVin and Triada the largest number of beans was formed in the early, the smallest - in the late sowing period. In the Knyazhna variety, the largest number of beans was formed during the early sowing period, while during the optimal and late sowing period, the deviations were insignificant.

The increase in the sowing rate to 900 thousand similar seeds caused a decrease in the number of beans in the variety Knyazhna - by 3-4 un., in the varieties Diadema Podillya and Khutoryanochka, respectively, by 5-9 un. and 6-9 un., in the Triada variety - by 8-10 un., while in the KiVin variety - by 13-14 un. compared with the sowing rate of 500 thousand similar seeds.

The shift of sowing dates to earlier caused an increase in the weight of 1000 seeds depending on the sowing rate in varieties KiVin - by 4,4-6,5\% and Triada - by 0,99,7\% and its decrease in varieties Diadema Podillya, Knyazhna and Khutoryanochka by $0,8-1,5 \%, 2,0-4,7 \%$ and $2,0-3,4 \%$, respectively. Sowing at a later date reduced the weight of 1000 seeds in varieties Diadema Podillya - by 0,8-6,6\% and Triadaby 3,4-7,2\%, while in varieties KiVin and Khutoryanochka deviation of this indicator was insignificant compared to the optimal sowing date. All studied soybean varieties with an increase in sowing rate from 500 to 900 thousand similar seeds reduced the weight of 1000 seeds, on average, by 0,5-13,9\% for all sowing dates.

Key words: plant height, number of beans, number of seeds, weight of 1000 seeds, individual productivity. 


\title{
ВПЛИВ СТРОКІВ СІВБИ ТА НОРМ ВИСІВУ НА БІОМЕТРИЧНІ ПОКАЗНИКИ СОРТІВ СОӤ З РІЗНИМ ВЕГЕТАЦІЙНИМ ПЕРІОДОМ
}

\author{
В. Г. Молдован, Ж. А. Молдован, С. І. Собчук \\ Хмельницька державна сільськогосподарська дослідна станція \\ Інституту кормів та сільського господарства Поділля НААН \\ с. Самчики, Старокостянтинівський р-н, Хмельницька обл., 31182, Україна
}

Пропозичія агровиробникам нових сортів сої обумовлює необхідність їх адаптаиії до певних трунтово-кліматичних умов вирощування та удосконалення окремих технологічних елементів (строків сівби, норм висіву тощь), що забезпечить високу їх продуктивність та максимальну реалізацію генетичного потенціалу.

За результатами проведених нами досліджень встановлено, що в усіх сортів збільшення норми висіву до 900 тис. схожих насінин зумовлювало зростання висоти прикріплення нижнього бобика, у середньому, на 1,0-6,8 см, тоді як ї̈ зменшення до 500 тис. схожих насінин призводило до зменшення цього показника на 0,9-5,7 см за усіх строків сівби.

Впродовж усього періоду досліджень сорти сої, залежно від строків сівби та норми висіву, формували різну кількість бобиків: Діадема Поділля - 23-33 шт., КиВін-26-44 шт., Княжна - 21-29 шт., Хуторяночка - 23-32 шт., Тріада - 28-38 шт. Однак, у сортів сої Діадема Поділля та Хуторяночка не спостерігалося істотної різниці за кількістю бобиків за різних строків сівби, тоді як у сортів КиВін та Тріада найбільша кількість бобиків формувалася за раннього, найменша - за пізнього строків сівби. У сорту Княжна найбільша кількість бобиків формувалася за раннього строку сівби, тоді як за оптимального та пізнього - відхилення були незначними.

Збільшення норми висіву до 900 тис. схожих насінин зумовлювало зменшення кількості бобиків у сорту Княжна - на 3-4 шт., у сортів Діадема Поділля та Хуторяночка, відповідно, на 5-9 шт. та 6-9 шт., у сорту Тріада - на 8-10 шт., тоді як у сорту КиВін - на 13-14 шт. порівняно з нормою висіву 500 тис. схожих насінин.

Зміщення строків сівби у більш ранні зумовлювало зростання маси 1000 насінин залежно від норми висіву у сортів КиВін - на 4,4-6,5\% та Тріада - на 0,9-9,7\% та їі зменшення у сортів Діадема Поділля, Княжна та Хуторяночка на 0,8-1,5\%, 2,0-4,7 \% та 2,0-3,4\%, відповідно.

Сівба у пізні строки зменшувала масу 1000 насінин у сортів Діадема Поділля - на 0,8-6,6\% та Тріада - на 3,4-7,2\%, тоді як у сортів КиВін та Хуторяночка відхилення иьього показника було незначним порівняно з оптимальним строком сівби. Усі досліджувані сорти сої за збільшення норми висіву з 500 до 900 тис. схожих насінин зменшували масу 1000 насінин, у середньому, на 0,5-13,9\% за усіх строків сівби.

Ключові слова: висота рослин, кількість бобиків, кількість насінин, маса 1000 насінин, індивідуальна продуктивність.

\section{Вступ}

Соя (Glycine max (L.)), 3 iї різноманітним використанням, $€$ важливою культурою на глобальному рівні. Нині вона стала стратегічною культурою і для України. Бурхливий розвиток соєсіяння зумовлений значним попитом на вищезазначену культуру та вимагає удосконалення елементів технології вирощування, що сприяє підвищенню іiі продуктивності. Саме тому сучасна технологія вирощування сої повинна грунтуватися на високій культурі землеробства, високоврожайних сортах нового покоління, застосуванні нової техніки, науково обгрунтованих норм добрив, ефективних препаратів бульбочкових бактерій, гербіцидів, оптимальних строків сівби, способів сівби та густоти рослин, збиранні без втрат, збереженні всього врожаю (Babich \& BabichPoberezhna, 2011; Gurigbal Singh, 2014).

Зокрема, правильний вибір сорту сої є одним iз найбільш доступних виробництву агрозаходів, що забезпечує пластичність культури до конкретних грунтово-кліматичний умов вирощування та гарантує одержання високих i стабільних урожаїв. У багатьох зарубіжних країнах в основу добору сортів сої та розміщення ix в різних грунтово-кліматичних умовах покладено тривалість світлового дня. В Україні ж, де лімітуючим фактором вирощування є тепло, а в деяких регіонах і волога, сорти сої добираються 
за тривалістю їх вегетаційного періоду (Ivanyuk, 2012; Kolisnyk, 2012).

Особливе значення має строк сівби насіння coï, адже це фактор виробництва, який не потребує додаткових затрат i, разом $з$ тим, може істотно впливати на продуктивність культури. Оскільки соя, порівняно 3 іншими сільськогосподарськими рослинами, має підвищені вимоги до тепла під час з'явлення сходів, то строки сівби є одним із найважливіших заходів збільшення їі врожаю, адже вони мають значний вплив на густоту стояння рослин та їх виживаність (Furman, 2017). Разом 3 тим, встановлено, що за ранніх строків сівби тривалість міжфазних періодів збільшується, тоді як за пізніх строків - скорочується. Загальна ж тривалість вегетаційного періоду та окремих міжфазних періодів визначається генетичними особливостями сортів сої різних груп стиглості (Polishchuk et. al., 2019).

Сдиного підходу до встановлення оптимального строку сівби наразі немає та все ж більшість науковців погоджуються 3 тим, що строк сівби визначається на основі таких факторів, як погодні параметри (наприклад, мінімальні та максимальні температури, фотоперіод, відносна вологість, опади) впродовж вегетаційного періоду культури, група стиглості, тип грунту, вологозабезпеченість під час сівби та ін., адже все це має значний вплив на формування показників індивідуальної продуктивності, урожайності (Shevnikov \& Lohvynenko, 2013; Tsekhmeystruk et. al., 2018) та якості насіння (Tsekhmeystruk et. al., 2016).

Соя $є$ світлолюбною культурою, тому формування високого урожаю забезпечується завдяки оптимальній площі живлення та густоті стояння рослин, достатній забезпеченості рослин вологою і необхідними поживними речовинами, а також освітленню листкової поверхні (Ivanyuk, 2012; Furman, 2018). Зміна густоти рослин сої впливає на інтенсивність використання основних факторів, необхідних для росту і розвитку рослин, a їх взаємодія визначає величину врожаю та його структуру (Shevnikov \& Lohvynenko, 2013).

Дослідженнями, проведеними у різних грунтово-кліматичних зонах, встановлено, що для пізньостиглих високорослих сортів сої 3 розкидною формою рослин, які добре гілкуються i формують багато листків, потрібна більша площа живлення, ніж для скоростиглих і низькорослих сортів, що менше гілкуються.
Таким чином, оптимальна густота стояння рослин для кожного сорту сої є необхідною умовою для отримання високих врожаїв насіння. Якщо густота посіву нижча оптимального рівня, ніякі способи не допоможуть отримати високий урожай насіння (Kolisnyk, 2012; Shepilova \& Petrenko, 2017; Shevnikov et. al., 2018).

Метою проведення наших досліджень було вивчити вплив різних строків сівби, норм висіву на ріст і розвиток рослин, формування показників індивідуальної продуктивності сортами сої вітчизняної селекції 3 різним вегетацій-ним періодом.

\section{Матеріали та методи дослідження}

Дослідження проводилися на Хмельницькій ДСГДС ІКСГП НААН впродовж 2016-2019 pр. Грунт дослідної ділянки - чорнозем опідзолений середньосуглинковий, слабозмитий, малогумусний на лесоподібному суглинку буруватопалевого забарвлення, має дрібно-горіхову структуру. У вологому стані - в'язкий. Орний горизонт 0-28 см, верхній перехідний - 36-81 см, нижній перехідний - 81-114 см, перехідний до породи - 114-138 см, 3138 см - порода (лесоподібний суглинок).

Грунт дослідних ділянок характеризується наступними показниками: достатньо насичений основами - 39,8-42,0 мг-екв. на 100 г, гідролітична кислотність - 1,8-2,7 мг-екв. на 100 г грунту, уміст гумусу (за Тюріним) - 3,2 \%, рухомими формами поживних речовин середньозабезпечений, а саме, уміст легкогідролізованого азоту - 14,4-16,6; фосфору - 11,0-12,0, калію - 7,8-8,0 мг на 100 г грунту.

Дослід передбачав вивчення п'яти сортів сої 3 різним вегетаційним періодом - Діадема Поділля, КиВін, Княжна, Хуторяночка та Тріада; трьох строків сівби - III декада квітня, I та II декади травня, п'яти норм висіву - 500, 600, 700,800 та 900 тис. схожих насінин на 1 га. Повторність досліду - триразова, площа посівної ділянки - $32 \mathrm{~m}^{2}$, облікової - $20 \mathrm{~m}^{2}$.

Спостереження за станом рослин, відбір рослинних зразків та облік урожаю насіння проводили згідно 3 зональними методичними рекомендаціями, ДСТУ та загальноприйнятими методиками проведення досліджень у рослинництві. Основним методом досліджень був польовий дослід - для вивчення дії та взаємодії організовуваних факторів, підрахунково-ваговий для встановлення параметрів показників 
структури врожаю та визначення врожайності насіння, методи математичної статистики - для визначення вірогідності результатів досліджень.

\section{Результати досліджень та обговорення}

Погодні умови вегетаційного періоду в роки проведення досліджень характеризувалися достатньо високими середньодобовими температурами, великою кількістю опадів 3 нерівномірним їх розподілом та значним дефіцитом у окремі фази розвитку сої, що мало істотний вплив на тривалість періоду «сівба сходи», ріст i розвиток рослин, формування показників їх індивідуальної продуктивності та урожайності насіння загалом (табл. 1).

Таблиия 1. Гідротермічні умови в роки проведення досліджень

\begin{tabular}{|c|c|c|c|c|c|c|c|}
\hline \multirow{2}{*}{ Рік } & \multicolumn{6}{|c|}{ Місяць } & \multirow{2}{*}{$\begin{array}{c}\text { За вегета- } \\
\text { ційний } \\
\text { період }\end{array}$} \\
\hline & квітень & травень & червень & липень & серпень & вересень & \\
\hline \multicolumn{8}{|c|}{ Середньодобова температура повітря, ${ }^{\circ} \mathrm{C}$} \\
\hline 2016 p. & 12,4 & 15,5 & 20,9 & 21,8 & 20,9 & 16,1 & 17,9 \\
\hline $2017 \mathrm{p}$. & 10,2 & 15,9 & 20,6 & 21,0 & 22,0 & 15,2 & 17,5 \\
\hline $2018 \mathrm{p}$. & 14,9 & 19,5 & 20,7 & 21,9 & 22,8 & 15,9 & 19,3 \\
\hline $2019 \mathrm{p}$ & 11,6 & 16,8 & 25,0 & 22,5 & 22,6 & 16,7 & 19,2 \\
\hline $\begin{array}{c}\text { Середнє за } \\
1960-2019 \text { pp. }\end{array}$ & 8,5 & 13,6 & 18,3 & 19,2 & 18,5 & 13,3 & 15,2 \\
\hline $\begin{array}{c}\text { Середнє за } \\
2016-2019 \text { pp. }\end{array}$ & 12,3 & 16,9 & 21,8 & 21,8 & 22,1 & 16,0 & 18,5 \\
\hline \multicolumn{8}{|c|}{ Сумарна кількість опадів, мм } \\
\hline 2016 p. & 51,4 & 78,0 & 283,3 & 92,3 & 15,4 & 8,8 & 529,2 \\
\hline $2017 \mathrm{p}$. & 35,3 & 48,6 & 120,8 & 89,4 & 106,0 & 203,8 & 603,9 \\
\hline $2018 \mathrm{p}$. & 21,3 & 49,9 & 190,7 & 146,9 & 28,6 & 76,9 & 514,3 \\
\hline 2019 p. & 73,5 & 302,4 & 94,1 & 127,9 & 54,8 & 54,9 & 707,6 \\
\hline $\begin{array}{c}\text { Середнє за } \\
\text { 1960-2019 рр. }\end{array}$ & 46,2 & 68,1 & 106,0 & 128,4 & 90,6 & 62,2 & 501,5 \\
\hline $\begin{array}{c}\text { Середнє за } \\
2016-2019 \text { рр. }\end{array}$ & 45,4 & 119,7 & 172,2 & 114,1 & 51,2 & 86,1 & 588,7 \\
\hline \multicolumn{8}{|c|}{ Гідротермічний коефіцієнт } \\
\hline $2016 \mathrm{p}$. & 1,38 & 1,62 & 4,52 & 1,37 & 0,24 & 0,33 & 1,58 \\
\hline $2017 \mathrm{p}$. & 1,15 & 0,99 & 1,95 & 1,37 & 1,55 & 4,47 & 1,91 \\
\hline $2018 \mathrm{p}$. & 0,48 & 0,83 & 3,07 & 2,17 & 0,40 & 1,72 & 1,45 \\
\hline 2019 p. & 2,10 & 5,74 & 1,25 & 1,82 & 0,78 & 1,08 & 2,12 \\
\hline $\begin{array}{c}\text { Середнє за } \\
1960-2019 \text { рр. }\end{array}$ & 1,81 & 1,61 & 1,62 & 2,16 & 1,63 & 1,51 & 1,72 \\
\hline $\begin{array}{c}\text { Середнє за } \\
2016-2019 \text { рр. }\end{array}$ & 1,28 & 2,29 & 2,70 & 1,68 & 0,74 & 1,90 & 1,76 \\
\hline
\end{tabular}

Проведені нами дослідження свідчать, що разом із умовами зволоження та температурним режимом впродовж вегетаційного періоду на показники висоти рослин сої та прикріплення нижнього бобика, елементи структури врожаю істотний вплив мали досліджувані чинники: сорт, строки сівби та норми висіву.

Зокрема, висота рослин сої на час збирання, у середньому за роки досліджень, становила: у сортів Діадема Поділля - 66,2-81,7 см; КиВін 76,0-92,8 см; Княжна - 83,1-106,4 см;
Хуторяночка - 69,1-85,5 см та Тріада - 79,6-93,8 см залежно від строку сівби та норми висіву (табл. 2). Нами відмічено певну залежність показників висоти рослин досліджуваних сортів сої від строків сівби та норм висіву. Так, у сортів сої Діадема Поділля та Хуторяночка висота рослин збільшувалася за зміщення строків сівби у більш ранні, відповідно, на 4,6-4,8 см, або 6,1-6,4 \%, та 6,4-7,5 см, або 7,7-9,0\%, або пізні на 5,3-9,3 см, або 6,7-11,7\%, та 3,7-4,6 см, або 4,7-5,8\%. У сортів КиВін та Княжна зміщення строків сівби у більш ранні призводило до зменшення висоти 
рослин, порівняно 3 оптимальним, на 2,5-4,7 см, або 3,0-4,9\%, та 6,2-10,3 см, або 7,0-11,6\%, відповідно. За сівби у пізні строки висота рослин цих сортів, навпаки, збільшувалася на 0,6-1,0 см, або $0,7-1,1 \%$, та 4,3-5,7 см, або 4,2-5,6\%. У сорту Тріада за сівби у ранні строки висота рослин сої збільшувалася, порівняно 3 оптимальним, на 1,4-4,2 см, або 1,6-4,5 \%, тоді як за сівби у пізні строки - зменшувалася на 0,6$3,2 \mathrm{cм}$, або $0,7-3,7 \%$.

\section{Таблиця 2. Висота рослин сої та прикріплення нижнього бобу залежно від строків сівби та норм висіву (середнс за 2016-2019 р.), см}

\begin{tabular}{|c|c|c|c|c|c|c|c|}
\hline \multirow[b]{3}{*}{ Сорт сої } & \multirow{3}{*}{$\begin{array}{c}\text { Норма } \\
\text { висіву, } \\
\text { тис. } \\
\text { схожих } \\
\text { насінин } \\
\text { на } 1 \text { га }\end{array}$} & \multicolumn{6}{|c|}{ Строки сівби сої } \\
\hline & & \multicolumn{2}{|c|}{ ранній } & \multicolumn{2}{|c|}{ оптимальний } & \multicolumn{2}{|c|}{ пізній } \\
\hline & & $\begin{array}{l}\text { висота } \\
\text { рослин }\end{array}$ & $\begin{array}{c}\text { висота } \\
\text { кріплення } \\
\text { нижнього } \\
\text { боба }\end{array}$ & $\begin{array}{l}\text { висота } \\
\text { рослин }\end{array}$ & $\begin{array}{c}\text { висота } \\
\text { кріплення } \\
\text { нижнього } \\
\text { боба }\end{array}$ & $\begin{array}{l}\text { висота } \\
\text { рослин }\end{array}$ & $\begin{array}{c}\text { висота } \\
\text { кріплення } \\
\text { нижнього } \\
\text { боба }\end{array}$ \\
\hline \multirow{3}{*}{$\begin{array}{l}\text { Діадема } \\
\text { Поділля }\end{array}$} & 500 & 70,8 & 10,2 & 66,2 & 10,2 & 71,5 & 9,0 \\
\hline & 700 & 74,8 & 12,3 & 70,2 & 11,8 & 79,1 & 9,9 \\
\hline & 900 & 77,2 & 13,8 & 72,4 & 14,0 & 81,7 & 10,9 \\
\hline \multirow{3}{*}{ КиВін } & 500 & 76,0 & 11,8 & 80,1 & 11,9 & 80,7 & 11,9 \\
\hline & 700 & 83,9 & 13,3 & 86,0 & 13,5 & 88,8 & 13,8 \\
\hline & 900 & 89,3 & 15,8 & 91,8 & 14,5 & 92,8 & 20,6 \\
\hline \multirow{3}{*}{ Княжна } & 500 & 83,1 & 14,2 & 89,3 & 15,0 & 93,6 & 20,3 \\
\hline & 700 & 88,6 & 18,4 & 91,4 & 19,9 & 101,5 & 23,6 \\
\hline & 900 & 90,4 & 21,7 & 100,7 & 21,5 & 106,4 & 25,3 \\
\hline \multirow{3}{*}{$\begin{array}{l}\text { Хуторя- } \\
\text { ночка }\end{array}$} & 500 & 76,6 & 13,2 & 69,1 & 13,3 & 73,7 & 13,9 \\
\hline & 700 & 83,1 & 15,1 & 74,0 & 14,7 & 78,6 & 17,0 \\
\hline & 900 & 85,5 & 16,9 & 79,1 & 16,8 & 82,8 & 19,7 \\
\hline \multirow{3}{*}{ Тріада } & 500 & 84,5 & 14,0 & 80,3 & 15,0 & 79,6 & 15,1 \\
\hline & 700 & 86,5 & 19,7 & 88,4 & 16,9 & 86,5 & 17,6 \\
\hline & 900 & 93,8 & 21,7 & 92,4 & 18,9 & 89,2 & 20,3 \\
\hline
\end{tabular}

Водночас, нами встановлено, що за усіх досліджуваних строків сівби збільшення норми висіву зумовлювало зростання висоти рослин сої усіх сортів, що вивчалися. Зокрема, у сорту Діадема Поділля висота рослин за норми висіву 900 тис. схожих насінин зростала на 2,2-2,6 см, або 3,1-3,3 \% порівняно 3 нормою висіву 700 тис. схожих насінин, тоді як за зменшення норми висіву до 500 тис. схожих насінин на 1 га зменшувалася на 4,0-7,6 см, або 5,6-9,6\%. У решти досліджуваних сортів ці показники становили, відповідно: КиВін - 4,0-5,8 см, або 4,5-6,7 \%, та 5,9-8,1 см, або 6,9-9,4\%; Княжна 1,8-9,3 см, або 2,0-10,2\%, та 2,1-7,9 см, або 2,37,8 \%; Хуторяночка - 2,4-5,1 см, або 2,9-6,9 \%, та 4,9-6,5 см, або 6,2-7,8 \%; Тріада - 2,7-7,4 см, або $3,1-8,5 \%$ та 2,0-8, 1 см, або 2,3-9,2\%.

Висота прикріплення нижнього бобика також залежала від досліджуваних чинників. Так, у сорту Діадема Поділля за раннього та оптимального строків сівби висота прикріплення нижнього бобика була майже однаковою - 10,213,8 см та 10,2-14,0 см, відповідно, тоді як за зміщення у пізні строки цей показник зменшувався до 9,0-10,9 см. У сорту КиВін за раннього та оптимального строків сівби висота прикріплення нижнього бобика становила, відповідно, 11,8-15,8 см та 11,9-14,5 см, тоді як за пізнього - зростала до 11,9-20,6 см. У сорту Княжна цей показник становив 14,2-21,7 см та 15,0-21,5 см, тоді як за пізнього строку сівби зростав до 20,3-25,3 см. У сорту Хуторяночка найбільша висота прикріплення нижнього бобу (13,9-19,7 см) відмічена також за пізнього строку сівби, тоді як за раннього та оптимального зменшувалася до 13,2-16,9 см та 13,3-16,8 см, відповідно. Показники висоти прикріплення нижнього бобика у сорту Тріада за раннього строку сівби становили 14,0-21,7 см, за сівби в оптимальні строки - зменшувалися до 15,0-18,9 см, за пізнього - зростали до 15,1-20,3 cм.

Варто зазначити, що в усіх досліджуваних сортів збільшення норми висіву до 900 тис. схожих насінин на 1 га зумовлювало підвищення висоти прикріплення нижнього бобика, у середньому за роки досліджень, у сортів Діадема 
Поділля та Хуторяночка на 1,0-2,2 см та 1,8-2,7 cм, відповідно, у сортів Княжна та Тріада - на 1,6$3,3 \mathrm{~cm}$ та 2,0-2,7 см, відповідно, тоді як у сорту КиВін - на 1,0-6,8 см. I, навпаки, зменшення норми висіву до 500 тис. схожих насінин призводило до зменшення висоти прикріплення нижнього бобика у сорту Діадема Поділля та КиВін на 0,9-2,1 см та 1,5-1,9 см, відповідно, тоді як у сортів Хуторяночка - на 1,4-3,1 см, Княжна на 3,3-4,9 см та Тріада на 1,9-5,7 см порівняно 3 нормою висіву 700 тис. схожих насінин на 1 га.

Рівень урожайності насіння сої прямо пропорційно залежить від індивідуальної продуктивності рослин, зокрема кількості насінин у бобиках, кількості бобиків на рослині, маси 1000 насінин тощо. У результаті проведеного структурного аналізу рослин сої досліджуваних сортів встановлено, що на показники індивідуальної продуктивності рослин впливають фактори: особливості сорту, строки сівби і норми висіву насіння, температурний режим і умови зволоження під час формування бобиків та наливу зерна.

Досліджено, що у середньому за роки проведення досліджень серед сортів сої з різним вегетаційним періодом найменшу кількість бобиків формували рослини сорту Княжна - 2129 шт., найбільшу - КиВін - 26-44 шт. та Тріада 28-38 шт. Рослини сортів сої Діадема Поділля та Хуторяночка формували практично однакову кількість бобиків: 23-33 шт. та 23-32 шт., відповідно (табл. 3).

Варто зазначити, що у сортів сої Діадема Поділля та Хуторяночка не спостерігалося істотної різниці за кількістю бобиків за різних строків сівби, тоді як у сортів КиВін та Тріада найбільша кількість бобиків формувалася за раннього строку сівби, найменша - за пізнього строку сівби. У сорту Княжна найбільша кількість бобиків формувалася за раннього строку сівби, тоді як за оптимального та пізнього - відхилення були незначними.

Водночас, усі досліджувані сорти за збільшення норми висіву зменшували кількість бобиків на 1 рослині. Зокрема, збільшення норми висіву до 900 тис. схожих насінин на 1 га зумовило, у середньому, зменшення кількості бобиків у сорту Княжна - на 3-4 шт., у сортів Діадема Поділля та Хуторяночка, відповідно, на 5-9 шт. та 6-9 шт., шт., у сорту Тріада - на 8-10 шт., тоді як у сорту КиВін - на 13-14 шт. порівняно 3 нормою висіву 500 тис. схожих насінин на 1 га.

Маса 1000 насінин $\epsilon$ ще одним показником, що характеризує індивідуальну продуктивність рослин сої та має значний вплив на формування урожайності. У середньому за роки досліджень маса 1000 насінин у досліджуваних сортів сої становила: у сортів Тріада та Діадема Поділля 143,1-170,1 г та 155,4-177,5 г, відповідно, у сортів КиВін та Хуторяночка - 125,2-143,2 г та 141,9- 157,8 г, відповідно, тоді як у сорту Княжна $111,8-126,4$ г. Аналізуючи вплив строків сівби на показники маси 1000 насінин, встановлено, що зміщення строків сівби у більш ранні зумовлювало зростання цього показника у сортів КиВін - на 5,6-8,8 г, або 4,4-6,5 \% та Тріада - на 1,3-15,1 г, або 0,9-9,7\% залежно від норми висіву. У сортів Княжна та Хуторяночка, навпаки, спостерігалося зменшення маси 1000 насінин, відповідно, на 3,1-5,5 г, або 2,0-4,7 \% та 3,2-5,0 г, або 2,0-3,4\%. У сорту Діадема Поділля спостерігалося незначне зменшення цього показника $(1,2-2,7$ г, або 0,8-1,5\%) порівняно 3 оптимальним строком сівби.

Зміщення строків сівби у більш пізні призвело до зменшення маси 1000 насінин у сортів Діадема Поділля - на 1,3-11,5 г, або 0,86,6 \% та Тріада - на 5,0-11,2 г, або 3,4-7,2\%, тоді як у сортів КиВін та Хуторяночка відхилення цього показника було неістотним порівняно 3 оптимальним строком сівби.

Збільшення норми висіву з 500 тис. схожих насінин до 900 тис. схожих насінин в усіх досліджуваних сортів сої зумовлювало зменшення маси 1000 насінин. Зокрема, у сорту Діадема Поділля цей показник зменшувався на 7,9-22,0 г, або 4,8-12,4 \%, у сорту КиВін - на 8,812,0 г, або 6,5-8,4 \%, у сорту Княжна - на 2,1-11,5 г, або $1,7-9,1 \%$, у сорту Хуторяночка - на 7,812,7 г, або $5,0-8,2 \%$ та у сорту Тріада - на $0,5-$ 20,7 г, або 0,5-13,9\%.

Разом 3 тим, нами встановлено, що за раннього строку сівби збільшення норми висіву зумовлювало зменшення маси 1000 насінин усіх досліджуваних сортів, у середньому, на 4,3-22,0 г, або 3,7-13,9 \%, за оптимального - на 2,1-18,1 г. або $1,7-10,4 \%$ та за пізнього - на $0,7-11,5$ г, або $0,5-9,1 \%$.

Оцінка досліджуваних технологічних елементів, проведена шляхом розрахунку індексу урожаю за формулою Дональда (Donald, 1968), показала, що за строками сівби відхилення цього показника було незначним, тоді як збільшення норми висіву призводило до його зменшення в усіх досліджуваних сортів сої. 
Таблиия 3. Формування елементів структури врожаю сортів сої з різним вегетаційним періодом залежно від строків сівби та норм висіву, середнє за 2016-2019 рр.

\begin{tabular}{|c|c|c|c|c|c|c|c|c|}
\hline \multirow[b]{3}{*}{ Copt cö̈ } & \multicolumn{4}{|c|}{500 тис. схожих насінин на 1 га } & \multicolumn{4}{|c|}{900 тис. схожих насінин на 1 га } \\
\hline & \multicolumn{2}{|c|}{ кількість, шт. } & \multirow{2}{*}{$\begin{array}{c}\text { мaca } \\
1000 \\
\text { насінин, } \\
\Gamma \\
\end{array}$} & \multirow[b]{2}{*}{$\begin{array}{c}\text { індекс } \\
\text { урожаю }\end{array}$} & \multicolumn{2}{|c|}{ кількість, шт. } & \multirow{2}{*}{$\begin{array}{c}\text { маса } \\
1000 \\
\text { насінин, } \\
\Gamma \\
\end{array}$} & \multirow[b]{2}{*}{$\begin{array}{c}\text { індекс } \\
\text { урожаю }\end{array}$} \\
\hline & $\begin{array}{c}\text { бобиків } \\
\text { на } \\
\text { рослині }\end{array}$ & $\begin{array}{c}\text { насінин } \\
\text { у } \\
\text { бобику }\end{array}$ & & & $\begin{array}{c}\text { бобиків } \\
\text { на } \\
\text { рослині }\end{array}$ & $\begin{array}{c}\text { насінин } \\
\text { у } \\
\text { бобику }\end{array}$ & & \\
\hline \multirow{6}{*}{$\begin{array}{l}\text { Діадема } \\
\text { Поділля }\end{array}$} & \multicolumn{8}{|c|}{ Ранній строк сівби (III декада квітня) } \\
\hline & 30 & 2,0 & 177,5 & 0,50 & 25 & 1,8 & 155,5 & 0,48 \\
\hline & \multicolumn{8}{|c|}{ Оптимальний строк сівби (I декада травня) } \\
\hline & 32 & 1,8 & 174,8 & 0,50 & 23 & 1,8 & 156,7 & 0,47 \\
\hline & \multicolumn{8}{|c|}{ Пізній строк сівби (II декада травня) } \\
\hline & 33 & 2,0 & 163,3 & 0,50 & 24 & 1,9 & 155,4 & 0,49 \\
\hline \multirow{6}{*}{ КиВін } & \multicolumn{8}{|c|}{ Ранній строк сівби (III декада квітня) } \\
\hline & 44 & 2,0 & 143,2 & 0,47 & 31 & 2,0 & 131,2 & 0,43 \\
\hline & \multicolumn{8}{|c|}{ Оптимальний строк сівби (I декада травня) } \\
\hline & 41 & 1,9 & 134,4 & 0,43 & 28 & 1,8 & 125,6 & 0,41 \\
\hline & \multicolumn{8}{|c|}{ Пізній строк сівби (II декада травня) } \\
\hline & 37 & 1,9 & 135,7 & 0,43 & 26 & 1,9 & 125,2 & 0,43 \\
\hline \multirow{6}{*}{ Княжна } & \multicolumn{8}{|c|}{ Ранній строк сівби (III декада квітня) } \\
\hline & 29 & 2,5 & 116,1 & 0,49 & 26 & 2,3 & 111,8 & 0,48 \\
\hline & \multicolumn{8}{|c|}{ Оптимальний строк сівби (I декада травня) } \\
\hline & 24 & 2,5 & 119,4 & 0,47 & 21 & 2,3 & 117,3 & 0,44 \\
\hline & \multicolumn{8}{|c|}{ Пізній строк сівби (II декада травня) } \\
\hline & 26 & 2,3 & 126,4 & 0,42 & 22 & 2,1 & 114,9 & 0,43 \\
\hline \multirow{6}{*}{ Хуторяночка } & \multicolumn{8}{|c|}{ Ранній строк сівби (III декада квітня) } \\
\hline & 32 & 2,0 & 154,6 & 0,49 & 25 & 2,1 & 141,9 & 0,48 \\
\hline & \multicolumn{8}{|c|}{ Оптимальний строк сівби (I декада травня) } \\
\hline & 30 & 2,0 & 157,8 & 0,49 & 24 & 1,9 & 146,9 & 0,46 \\
\hline & \multicolumn{8}{|c|}{ Пізній строк сівби (II декада травня) } \\
\hline & 32 & 2,0 & 155,2 & 0,49 & 23 & 1,8 & 147,4 & 0,46 \\
\hline \multirow{6}{*}{ Тріада } & \multicolumn{8}{|c|}{ Ранній строк сівби (III декада квітня) } \\
\hline & 38 & 2,0 & 170,1 & 0,47 & 28 & 1,9 & 149,4 & 0,43 \\
\hline & \multicolumn{8}{|c|}{ Оптимальний строк сівби (I декада травня) } \\
\hline & 37 & 2,0 & 155,0 & 0,47 & 29 & 1,7 & 148,1 & 0,42 \\
\hline & & & Пізній & грок сівбі & (II декада & гравня) & & \\
\hline & 28 & 2,0 & 143,8 & 0,44 & 28 & 1,9 & 143,1 & 0,41 \\
\hline
\end{tabular}

У середньому за роки досліджень індекс урожаю становив для сортів Діадема Поділля $0,47-0,50$ ум. од., Хуторяночка $-0,46-0,49$ ум. од., Княжна - 0,42-0,49 ум. од.,КиВін та Тріада 0,41-0,47 ум. од. Варто зазначити, що за результатами досліджень, проведених у соєсіючих країнах, оціночні показники індексу урожаю сої становлять, у середньому, 0,50 ум. од., змінюючись в діапазоні від 0,35 ум. од. до 0,65 ум. од. (Gurigbal, 2014).

\section{Висновки}

1. Встановлено, що досліджувані чинники у взаємодії 3 гідротермічними умовами вегетаційного періоду мали значний вплив на формування показників індивідуальної продуктивності рослин сої усіх досліджуваних сортів: кількість бобиків на рослині та насінин у бобику, масу 1000 насінин, вагу насіння з 1 рослини тощо.

2. В усіх досліджуваних сортів збільшення норми висіву до 900 тис. схожих насінин зумовлює підвищення висоти прикріплення нижнього бобика, у середньому за роки досліджень, на 1,0-6,8 см, тоді як зменшення норми висіву до 500 тис. схожих насінин зменшення цього показника на $0,9-5,7 \mathrm{~cm}$.

3. Строки сівби не мають істотного впливу на формування кількості бобиків у сортів сої Діадема Поділля та Хуторяночка, тоді як у сортів КиВін та Тріада найбільша кількість бобиків 
формується за раннього строку сівби, найменша за пізнього строку сівби. У сорту Княжна найбільша кількість бобиків формується за раннього строку сівби, тоді як за оптимального та пізнього - відхилення були незначними.

4. Збільшення норми висіву до 900 тис. схожих насінин на 1 га зумовлює зменшення маси 1000 насінин в усіх досліджуваних сортів сої за раннього строку сівби, у середньому, на 4,3-22,0 г, або 3,7-13,9\%, за оптимального - на 2,1-18,1 г, або $1,7-10,4 \%$ та за пізнього - на 0,7-11,5 г, або 0,5-9,1\% порівняно 3 нормою висіву 500 тис. схожих насінин на 1 га.

5. Індекс урожаю істотно змінювався лише за нормами висіву та становив, у середньому за роки досліджень, для сортів Діадема Поділля 0,47-0,50 ум. од., Хуторяночка - 0,46-0,49 ум. од., Княжна - 0,42-0,49 ум. од., КиВін та Тріада $0,41-0,47$ ум. од.

6. Розвиток селекційного процесу та поява нових сортів сої обумовлює необхідність продовження досліджень щодо їх адаптації до певних грунтово-кліматичних умов вирощування, удосконалення окремих технологічних елементів (строків сівби, норм висіву, системи живлення тощо), що забезпечить високу їх продуктивність та максимальну реалізацію генетичного потенціалу.

\section{References}

Babych, A. O. \& Babych-Poberezhna, A. A. (2011). Selektsiia, vyrobnytstvo, torhivlia i vykorystannia soi u sviti [Soybeans breeding, production, traiding and world use]. Kyiv : Ahrarna nauka [in Ukrainian].

Donald, C. M. (1968). In search of yield. Journal of Australian Institute of Agricultural Sciense, 28, 171-178.

Furman, O. V. (2017). Hustota stoyannya roslyn soi ta yiyi vyzhyvanist zalezhno vid strokiv sivby ta sortu [Soybean plant density and their survival depending on the sowing terms and varieties]. Kormy i kormovyrobnytstvo, 83, 83-89 [in Ukrainian].

Furman, O. V. (2018). Dynamika formuvannya ploshchi lystkovoyi poverkhni soi pid vplyvom tekhnolohichnykh faktoriv vyroshchuvannya [Dynamics of soybean leaf surface area formation under the influence of technological factors of growing]. Kormy i kormovyrobnytstvo, 86, 101-106 [in Ukrainian].

Gurigbal, S. (2014). Soya: biologija, proizvodstvo, ispolzovanie [The Soybean: Botany, Production and Uses]. Kiyev : Zerno [in Russian].

Ivaniuk, S. V. (2012). Formuvannia sortovykh resursiv soi vidpovidno do bioklimatychnoho potentsialu rehionu vyroshchuvannia [Formation of variety resources of soybean in accordance with bioclimatic potential of the region of cultivation]. Kormy $i$ kormovyrobnytstvo, 71, 34-40 [in Ukrainian].

Kolisnyk, S. I. (2012) Osnovni tekhnolohichni pryiomy vyroshchuvannia soi na nasinnia [Basic technological methods of soybean cultivation for seed]. Kormy i kormovyrobnytstvo, 71, 41-48 [in Ukrainian].

Polishchuk, I. S., Polishchuk, M. I. \& Yurchenko, N. A. (2019). Tryvalist periodu vehetatsii ta mizhfaznykh periodiv sortiv soi zalezhno vid strokiv sivby ta norm vysivu [The duration of the growingseason and the interphase periods of soybean varieties depending on the timing of sowing and seeding rates]. Silske hospodarstvo ta lisivnytstvo, 15, 64-71. doi: 10.37128/2707-5826-2019-4-6 [in Ukrainian].

Shepilova, T. P. \& Petrenko, D. I. (2017). Vplyv sposobu sivby i normy vysivu nasinnia na rist $\mathrm{i}$ rozvytok roslyn soi [Influense of seeding methods and rates on the growth and development of soybean]. Visnyk Umanskoho natsionalnoho universytetu sadivnytstva, 1, 74-77 [in Ukrainian].

Shevnikov, M. Ya. \& Lohvynenko, O. M. (2013). Vplyv strokiv, sposobiv sivby, norm vysivu riznykh sortiv soi na yii produktyvnist [Influence of terms, methods of sowing and norms of sowing of different sorts of soy on its productivity]. Visnyk Poltavskoi derzhavnoi ahrarnoi akademii, 1, 12-16 [in Ukrainian].

Shevnikov, M. Ya., Milenko, O. H.\& Lotysh, I. I. (2018). Urozhainist sortiv soi zalezhno vid elementiv tekhnolohii vyroshchuvannia [The productivity of soy sorts depending on elements of growing technology]. Visnyk Poltavskoi derzhavnoi ahrarnoi akademii, 3, 15-21. doi: 10.31210/visnyk2018.03.02 [in Ukrainian].

Tsekhmeistruk, M. H., Sheliakin, V. O. \& Hlubokyi, O. M. (2016). Yakist nasinnia sortiv soi zalezhno vid strokiv sivby $\mathrm{v}$ skhidnomu Lisostepu Ukrainy [Quality of soybean varieties depending on sowing dates in the Eastern Forest-Steppe of Ukraine]. Kormy i kormovyrobnytstvo, 82, 39-44 [in Ukrainian].

Tsekhmeistruk, M. H., Sheliakiv, V. O., Shevnikov, M. Ya. \& Lytvynenko, O. S. (2018). Vplyv strokiv sivby na urozhainist sortiv soi [The influence of sowing dates on the yield capacity of soybeans sorts]. Visnyk Poltavskoi derzhavnoi ahrarnoi akademii, 1, 35-41. doi: 10.31210/visnyk2018.01.05 [in Ukrainian]. 